\title{
ULTRASTRUCTURAL ALTERATIONS OF CHOROID PLEXUSES OF LATERAL VENTRICLES OF RATS (RATTUS NORVEGICUS) SUBMITTED TO EXPERIMENTAL CHRONIC ALCOHOLISM
}

\author{
LUIS FERNANDO TIRAPELLI*, OISENYL JOSÉ TAMEGA**, SIDNEI PETRONI*
}

\begin{abstract}
Adult male rats (Wistar lineage) were alcoholized with sugar cane liquor diluted at $30^{\circ} \mathrm{GL}$ during 300 days and sacrificed every 60 days in 5 stages. Samples of choroid plexuses of lateral ventricles were collected and examined at transmission electronic microscope to detect possible ultrastructural alterations and to raise possible pathological correlations. Gradual changes were observed in these animals during all the experiment: dilatation and enlargement of cisternae of Golgi complex, dilatation of RER, presence of digestive vacuoles and a large amount of pinocytic vesicles as well as vesicles with electronlucent content throughout cytoplasm, as well as an enlargement of intercellular space between basolateral interdigitation of the cells and of the connective tissue. The changes observed in the epithelium and connective tissue of choroid plexuses specially in 240 and 300 days of treatment are presumably due to a disturbance in hydroelectrolitic homeostasis, contributing to several morpho-functional disturbs of central nervous system. No changes were observed in the control group animals.
\end{abstract}

KEY WORDS: chronic alcoholization, choroid plexus, rats, morphologic alterations.

\section{Alterações ultraestruturais dos plexos coróides dos ventrículos laterais de ratos (rattus norvegicus) submetidos a alcoolismo crônico experimental}

RESUMO - Ratos machos adultos (linhagem Wistar) foram alcoolizados com aguardente de cana diluída a $30^{\circ}$ GL durante 300 dias e sacrificados a cada 60 dias em 5 etapas. Amostras dos plexos coróides dos ventrículos laterais foram coletadas e examinadas ao microscópio eletrônico de transmissão para detectar possíveis alterações ultraestruturais e suas correlações patológicas. Alterações graduais foram observadas nestes animais durante todo o experimento: dilatação e aumento das cisternas de complexo de Golgi, dilatação do retículo endoplasmático rugoso, presença de vacúolos digestivos e grande quantidade de vesículas pinocíticas assim como de vesículas de conteúdo elétron-lúcido por todo o citoplasma, além de aumento do espaço intercelular, entre as interdigitações das células assim como no tecido conjuntivo. As alterações observadas no epitélio e no tecido conjuntivo dos plexos coróides, especialmente aos 240 e 300 dias de tratamento, são devidas possivelmente a distúrbios na homeostase hidro-eletrolítica, podendo assim contribuir para vários distúrbios morfo-funcionais do sistema nervoso central. Nenhuma alteração foi observada nos animais do grupo controle.

PALAVRAS-CHAVE: alcoolização crônica, plexo coróide, ratos, alterações morfológicas.

Studies conducted in experimental animals as well as in man showed that excessive consumption of alcohol involves mainly the central nervous system(CNS $)^{1}$ So, Clair $^{1}$ observed that $40 \%$ to $70 \%$ of chronic alcoholics show an enlargement of encephalic ventricles and cortical reduction ${ }^{1}$. According to Fortes ${ }^{2}$, the difusion of ethanol through the hemato-encephalic barrier occurs

Department of Anatomy, Institute of Biosciences (IB), State University of São Paulo, (UNESP), Botucatu/ SP, Brazil: *Post-Graduating; **Professor. Aceite: 18-outubro-1999.

Dr. Oisenyl José Tamega - Department of Anatomy - Institute of Biosciences, UNESP, Rubião Júnior s/nº 18618-000 - Botucatu SP - Brasil. Fax 014821 3744. E-mail: anatomia@ibb.unesp.br ou tirapeli@mailcity.com. 
in the CNS at a very high speed. Goldstein (1984) and Traschi \& Rubin (1985) observed in adult rats that ethanol modifies physical properties of cerebral biomembranes (cited by Renau-Piqueras et al. $)^{3}$. Ultrastructural changes were observed by Checiu et al. ${ }^{4}$ in fetal neo-cortex of rats due to chronic maternal alcoholization. He also observed some ultrastructural changes in choroid plexuses of rat fetuses due to chronic maternal alcoholization such as increased stroma in connecting tissue, enlargement of intercellular space and volume of Golgi complex as well as swelling and vacuolization of mitochondria. As the main responsible organ for the elaboration of cerebrospinal fluid (CSF), the observed changes in choroid cells probably alter the morphofunctional integrity of these cells. Therefore the aim of this work was to detect the possible ultrastructural alterations at transmission electron microscope level in choroid plexuses of lateral ventricles of chronically alcoholized rats.

\section{METHOD}

Forty male adult rats (Wistar lineage) were used, weighing approximately $250 \mathrm{~g}$ and aged 3 months at the beginning of the experiment. The experiment was scheduled for a period of 300 days and sacrifices were conducted in 5 stages at every 60 days. At the end of each treatment period (60, 120, 180, 240 and 300 days) 4 animals per group were sacrificed. Animals were divided in 2 groups of 20 animals each with the following characteristics according to liquid diet: control group (C): tap water daily ad libitum; alcoholic experimental group (A): sugar cane liquor, at $30^{\circ} \mathrm{GL}$, daily. Both groups had the same weekly amount of solid diet (Purina ration).

For the accomplishment of this experiment pseudo-volunteer alcoholism model was used so that alcohol was the only liquid food provided to group A animals. In order to avoid a considerable loss of animals, the alcoholic experimental group was submitted to a brief and gradual adaptation period regarding alcohol consumption which consisted of liquid diet gradually changed as follows: first week diluted alcohol at $10^{\circ} \mathrm{GL}$; second week, diluted alcohol at $20^{\circ} \mathrm{GL}$ and at third week, diluted alcohol at $30^{\circ} \mathrm{GL}$. At the end of the third week the experimental stage began.

After collection, the material was fixed using perfusion method with glutaraldehyde at $2,5 \%$, processed for routine electronic microscopy, stained with uranil and lead citrate and examined in a EM 301 Philips Transmission Electron Microscope.

\section{RESULTS}

Ultrastructurally the secretory epithelium of choroid plexuses is described as a simple colunar type, showing on the ventricular surface, curved and irregular cytoplasmatic projections, the microvilli (Fig 1), besides the occasional presence of cilia (Fig 1). Cytoplasm has a large nucleus, in central position (Fig 2), a great amount of mitochondria, RER as well as Golgi complex (Fig 1 and 2) which is placed mainly at the apical surface of cells and the occasional presence of lysosomes (Fig 2). Among apical termination of epithelial contigual cells, the unitive complex is formed by the following junctions: occlusive zonule, adhesive zonule and desmosomes (Fig 3). Basolateral membrane of choroid cells shows considerable interdigitations (Fig 2). Choroid cells lie over a dense basal and continuous lamina and below it there is a scarce stroma of loose connective tissue (Fig 2) showing mainly collagen fibers. This connective tissue separates choroid cells from central capillaries made up by a thin endothelium. In animals from group A gradual ultrastructural changes were observed in all periods of the experiment. Refering to cytoplasmatic organelle it was found an increase in volume of RER cisternae (Fig 4 and 6); Golgi complex was a little expanded (Fig 6) and its cisternae sometimes had a great amount of expanded vesicles (Fig 8). It was also noted that all over the cytoplasm there were concentric membranes similar to myelin pictures (Fig 4 and 7). An enlargement of intercellular space (Fig 9 and 11) was also observed and choroid cells were still united by elements of the unitive complex. Besides the observed alterations during all the experimental period other were also noted that: in the cytoplasm there were several sized vesicles containing electronlucent material (Fig 10, 11 and 12); an increase and accumulation of primary and secondary lysosomes (Fig 5), a swelling as big digestive vacuoles (Fig 7) and presence of vesicles containing heterogeneous material (Fig 10 and 12). On the plasma membrane of the apical region of choroid cells it was observed the presence of a great quantity of pinocytic vesicles (Fig 10). There was also a dilatation in the space between basal interdigitations of choroid cells and the space occupied by connective tissue (Fig 9 and 11). 


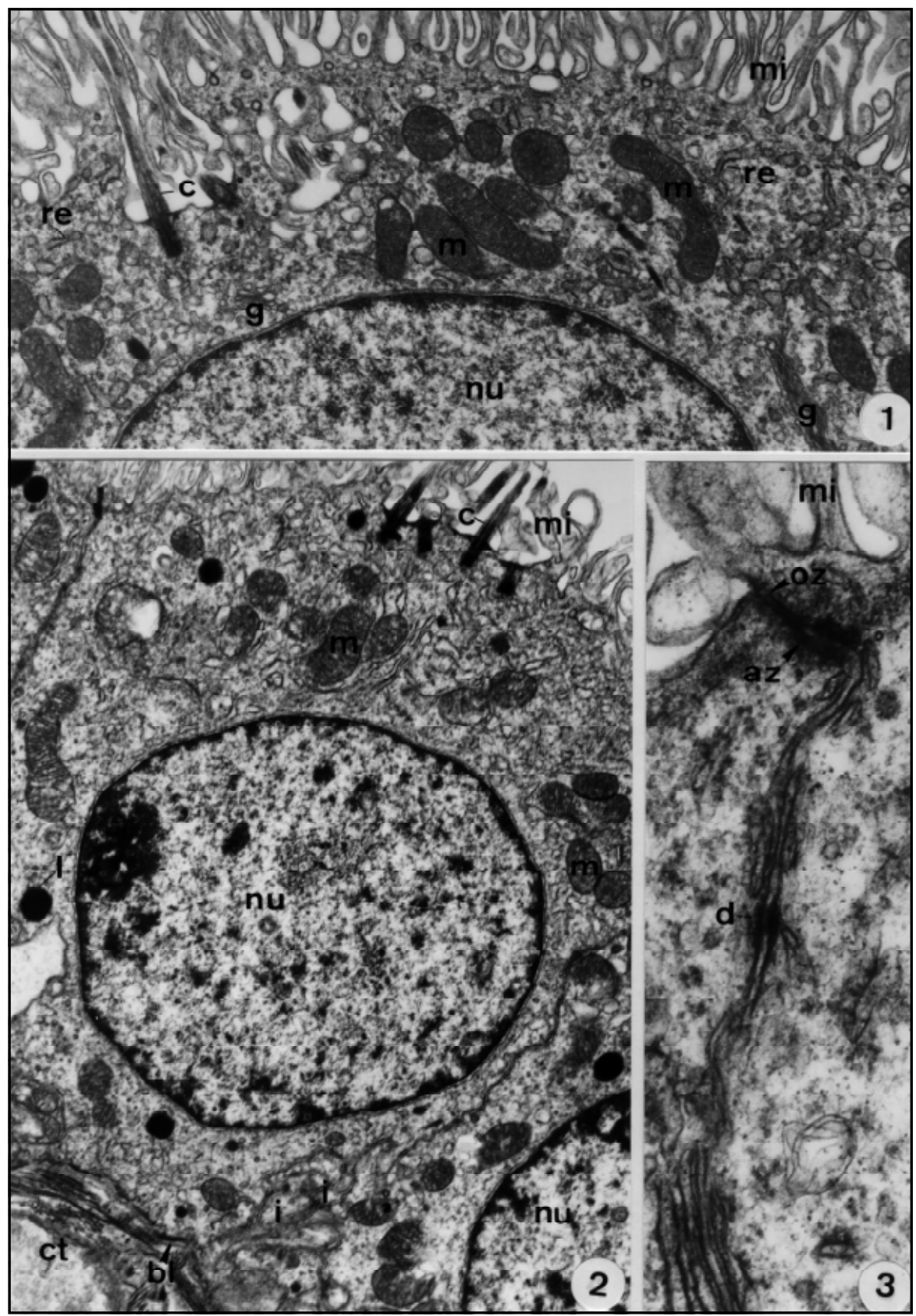

Fig 1-3. Electromicrography of choroid plexuses of lateral ventricles in control rats.

Fig 1. Apical portion of a choroid cell. Cilium (c); Golgi complex ( $g$ ); microvilli (mi); mitochondria (m); nucleus (nu); rough endoplasmatic reticulum (re). x13000.

Fig 2. Choroid villi. Basal lamina (bl); cilia (c); connective tissue (ct); interdigitation (i); lysosome (l); microvilli (mi); mitochondria (m); nucleus (nu). x5000.

Fig 3. Junctional complex. Adhesion zonule (az); desmosome (d); microvilli (mi); oclusion zonule (oz). $x 50000$. 


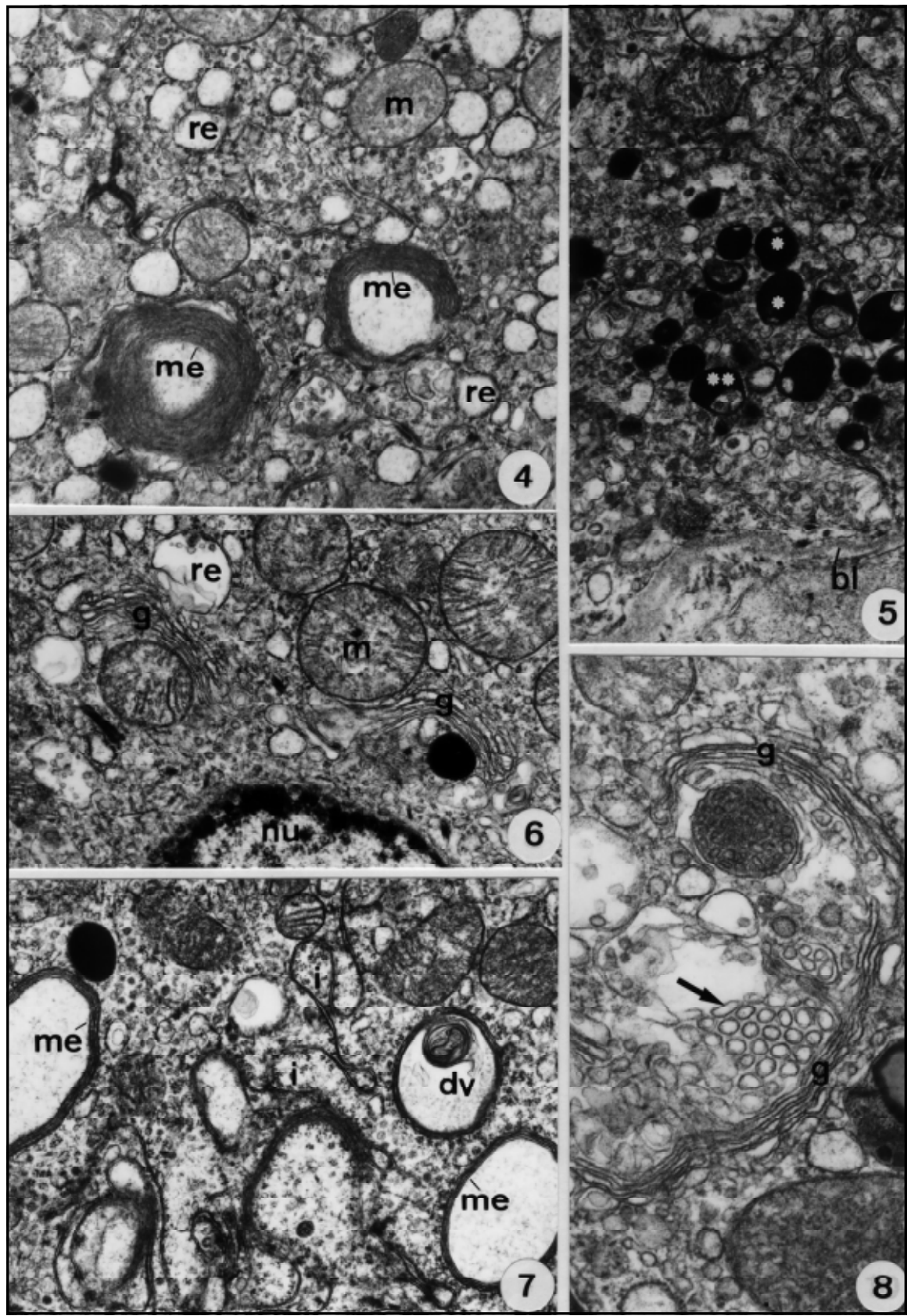

Fig 4-8. Electromicrography of choroid plexuses of lateral ventricles of alcoholic rats with 60 and 120 days of treatment. Fig 4 and 6. It is observed an increase in the number of rough endoplasmatic reticulum (re) and Golgi complex $(\mathrm{g})$ besides the presence of concentric membranes similar to myelin pictures (me). Mitochondria (m); nucleus (nu). x21000; x16500. Fig 5. Primary lysosome (*) and secondary ones (**). Basal lamina (bl). x21000. Fig 7. Space between two choroid epithelial cells where it is observed a great vesicle showing concentric membranes similar to myelin pictures (me) besides a digestive vacuole ( $d v)$; interdigitations $(i)$. $x 21000$. Fig 8. Golgi complex ( $g$ ) showing a great quantity of vesicles widely expanded (arrow). $x 27500$. 


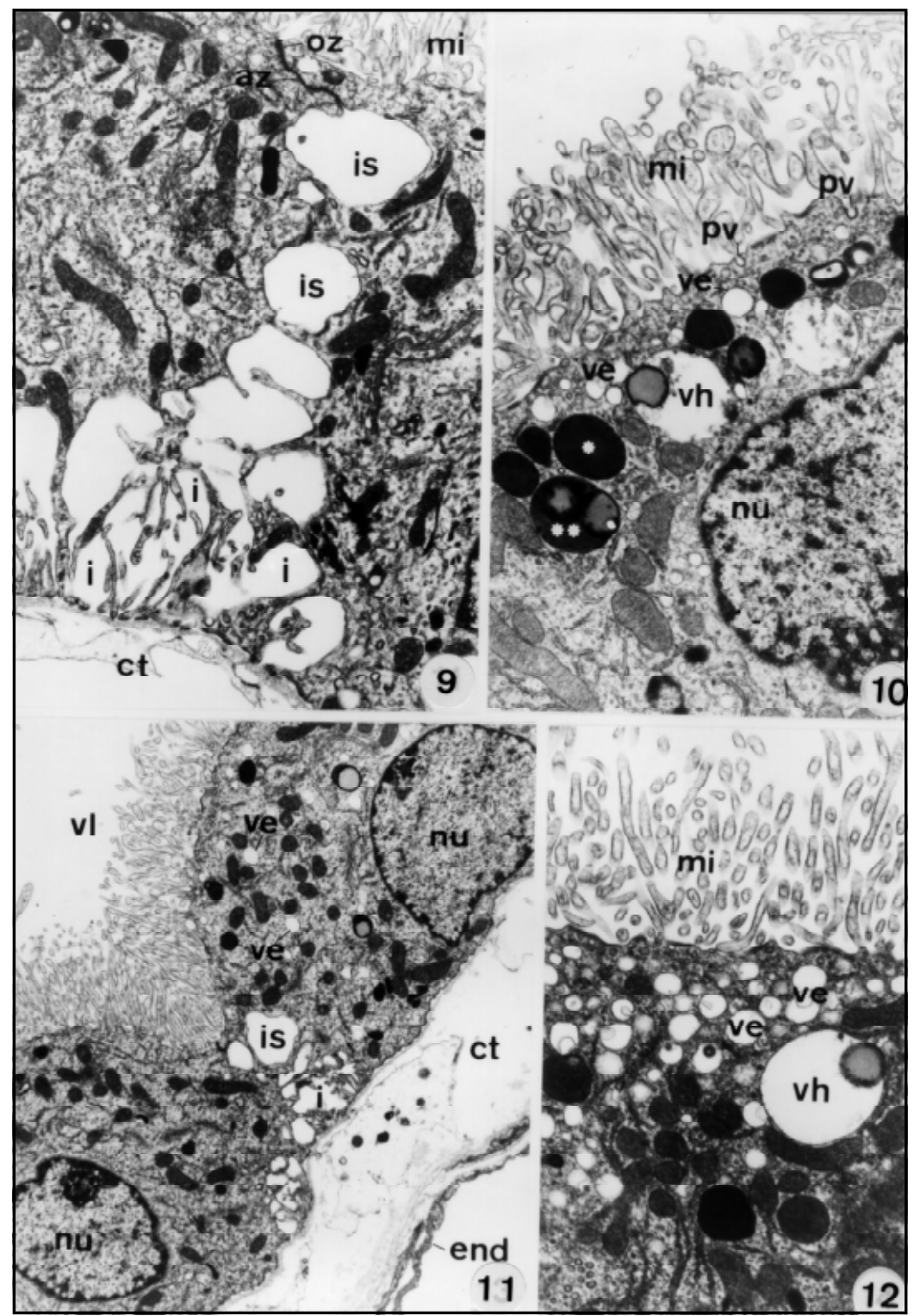

Fig 9-12. Electromicrography of choroid plexuses of lateral ventricles of alcoholic rats with 180, 240 and 300 days of treatment. Fig 9. Expanded intercellular space (is) and separated basolateral interdigitations (i). Note the maintainance of occlusion zonule (oz) and adhesion zonule (az) at apical portion of choroid cells. Connective tissue (ct); microvilli (mi). x13000. Fig 10. Apical portion of cell where it is observed a pinocytic vesicles $(p v)$ along with apical surface of cell membrane; vesicles with heterogeneous material $(v h)$ besides small vesicles containing electronlucent material (ve). Primary lysosome (*) and secondary (**); microvilli (mi); nucleus (nu). x16500. Fig 11. Expanded intercellular space (is); separated basolateral interdigitations ( $i$ ) and connective tissue widely spread (ct). Endothelium (end); nucleus ( $\mathrm{nu})$; ventricular lumen ( $\mathrm{vl}$ ); vesicles containing electronlucent material (ve).x8000. Fig 12. Detail of apical portion of cytoplasm of a choroid cell where it is observed a great number of vesicles containing electronlucent material (ve) besides the presence of a vesicle containing heterogeneous material (vh). Microvilli (mi). x16000. 


\section{DISCUSSION}

Choroid plexuses are present in lateral ventricules (central part and lower horn) and in the roof of ventricules III and IV. Since the last century several authors confer them the function, among others, of participating in the production of CSF due to some morphological characteristics presented by choroid epithelium such as its great content of mitochondria, the presence of pinocytic vesicles in apical region of its cells, interdigitated and twisted basolateral surfaces (Fig 2) and the presence of an occlusion zonule (Fig 3) between lateral sides of choroid cells ${ }^{5-10}$. Based on these characteristics, Maxwell \& Pease ${ }^{11}$ noted ultrastructurally that such peculiarity of the basolateral membrane of epithelium and choroid cells and the presence of microvilli on their apical surface result in a great enlargement of cell surface area, and it seems that this may help fluid transport. Endothelium of choroid capillar is irregular and fenestrated and can also show a specialization of such organ to facilitate the fluid transport. It is known that the CNS is more frequently affected by alcohol due to its great affinity with such drug. When alcohol is drunk it is rapidly absorbed and reaches, in a short time, levels which show symptoms of acute intoxication. It is supposed that 2 to 6 hours after its ingestion, the alcoholic concentration in the CNS is close to that found in the blood, being the responsible factors the neurotropism of alcohol and the great blood irrigation of $\mathrm{CNS}^{2}$. So in adult rats ethanol changes physical properties of cerebral biomembranes (Goldstein, 1984 and Taraschi \& Rubin, 1985 cited by Renau-Piqueras et al. $)^{3}$ affecting the cerebral vascular permeability ${ }^{12}$ easily crossing the hemato-encephalic barrier, spreading itself by diffusion to the interior of adjacent tissues ${ }^{13}$ and resulting in histopathological and chemical alterations of the brain ${ }^{14-15}$. As it was suggested by Jarnefelt ${ }^{16}$ alcohol prevents the active transport mechanism of sodium through choroid plexuses, which explains the several effects of alcohol in intact nervous cells. A disorder in fluid and electrolite distribution was shown by Nicholson \& Taylor (1938) who observed after alcohol ingestion a diuresis of sodium, potassium, chloride and nitrogen retention (cited by Horsey) ${ }^{17}$. So, due to such results we can suggest a probable modification in the ionic balance of CSF and consequently its homeostasis.

Several alterations were observed in alcoholic animals in choroid cells as well as in axial structures of villi. Thus enzymatic changes as well as changes in the membranes, induced by ethanol or its direct action, may lead to problem in circulation of fluids among membranes, being the responsible for cerebrospinal fluid accumulation in intercell space and between capillaries and choroid epithelium thus contributing to the impairment in the production of cerebrospinal fluid by choroid plexuses ${ }^{3,18,19}$. Vesicles containing electronlucent material were observed all over the cytoplasm due to a greater penetration of fluid in cytoplasm of choroid cells resulting from fluid accumulation in intercellular space and connective tissue. Concerning the presence of a great quantity of lysosomes, secondary lysosomes and digestive vacuoles it is suggested that this occurs due to problems in secretion and absorption of products in CSF or to death of some cytoplasmatic organelles or even to direct action of alcohol.

It is known today that choroid plexuses are the main structures responsible for the elaboration and maintainance of homeostasis of CSF, an essential factor for a normal development and function of CNS. So the possible harmful effects in morpho-functional integrity of this organ may alter the hematoliquor barrier (and indirectly the blood-brain barrier) and induce pre and postnatal disorders in $\mathrm{CNS}^{19}$.

The changes observed are presumably due to a disturbance in hydroelectrolite homeostasis and the changes caused by alcohol in cerebral membranes are appropriate and complementary to this supposed hypothesis, possibly being responsible, at least, for some of the pathologies of the CNS in alcoholics, such as the neurochemical level that affect the function of GABA, glutamatergic, serotonergic, dopaminergic, cholinergic, and opioid neuronal systems, observed by Eckardt et al. ${ }^{20}$. So, the ethanol can affect these systems directly, and/or the interations between and among these systems. The moderate consumption of ethanol by pregnant women can have significant consequences on the developing nervous system of the fetus (behavioral, cognitive anomalies) ${ }^{20}$, also observed by Checiu et al. ${ }^{4}$ in the mouse fetal CNS of variable severity, from major malformations (microcephaly, microgyry, hydrocephaly) to fine, morpho-functional modifications leading to various neuro-psychical and behavioral disturbances. 


\section{REFERENCES}

1. Clair HRSt. Recognizing alcoholism and its effects: a mine-guide. Basel: S. Karger, 1991.

2. Fortes AJR. Alcoolismo. São Paulo: Sarvier. 1975.

3. Renau-Piqueras J, Miragall F, Marques A, Bguena-Cervellera R, Guerri C. Chronic ethanol consumplion affects FilipinCholesterol complexes and intramembranous particles of synaptosomes of rat brain cortex. Alcohol Clin Exp Res 1987;11:486-493.

4. Checiu I, Craciun C, Craciun V. Ultrastructural changes in the mouse fetal neocortex following chronic maternal alcoholization. Morphol Embryol 1989;35:3-8.

5. Meek WJ. A study of the choroid plexus. J Comp Neurol Psychol 1907;17:286-306.

6. Millen JW, Rogers GE. An electron microscopic study of the choroid plexus in the rabbit J Biophys Biochem Cytol $1956 ; .2: 407-416$.

7. Tennyson VM, Pappas GD. Electron microscope studies of developing telencephalic choroid plexus in normal and hydrocephalic rabbits. In Fields WS, Desmond MM. (eds). Disorders of the developing nervous system Springfield: Thomas, 1961;267-398.

8. Tennyson VM, Pappas GD. Fine structure of the developing telencephalic and myelencephalic choroid plexus in the rabbit. J Comp Neurol 1964;123:379-412.

9. Dohrmann GJ. The choroid plexus: a historical review. Brain Res 1970;18:197-218

10. Webster PP. The fine structure of the nervous system, the nervous and supporting cells.Philadelphia: Saunders, 1976:280-294.

11. Maxwell DS, Pease DC. The electron microscopy of the choroid plexus. J Biophys Biochem Cytol 1956;2:467-474.

12. Davson H. The blood-brain barrier. In Bourne GA. The structure and function of nervous tissue. New York: Academic Press, 1972;4:323-445.

13. West JR, Dewey SL, Pierce DR, Black AC Jr. Prenatal and early postnatal exposuse to ethanol permanently alters the rat hippocampus. In Mechanism of alcohol damage in utero. London: Ciba Foundation: 1984:8-25. Ciba Foundation Symposium 105.

14. Wallgren H. Effects of acetylcholine analogues and ethanol on the respiration of brain cortex tissue in vitro. Biochem Pharmacol 1961;6:195-204.

15. Rosenfeld G. Potentation of the narcotic action and acute toxicity of alcohol by primary aromatic monoamines. Q J Stud Alcohol 1960;21:584-96.

16. Jarnefelt JA possible mechanism of action ethyl alcohol on the central nervous system. Ann Med Exp Biol Fenniae 1961;39:267-288.

17. Horsey WJ. The effect of acute alcoholism intoxication on the bood-brain barrier. J Neuropathol 1953;12:368-372.

18. Renau-Piqueras J, Miragall F, Guerri C, Sancho-Tello M, Bguena-Cervellera R. Prenanal exposure to ethanol alters lateral plasma membranes and grap junctions of newborn rat hepatocytes as revealed by freeze-fracture. J Submicrosc Cytol 1978;19:397-404.

19. Craciun C, Checiu I, Craciun V. Ultrastructural changes in the mouse fetal choroid plexuses following chronic maternal alcoholization. Rev Roum Morphol Embryol Physiol 1989;35:221-226.

20. Eckardt MJ, File SE, Gessa GL, et al.. Effects of moderate alcohol consumption on the central nervous system. Alcohol Clin Exp Res 1998;22: 998-1040. 